\title{
ANALYSIS EFFECT OF COMMODITIES CRUDE OIL AND COAL IN INDONESIA STOCK EXCHANGE
}

\author{
H. Hersugondo ${ }^{1}$, Rio Dhani Laksana ${ }^{2}$, Viviana Mayasari ${ }^{3}$ \\ 1 Faculty of Economics and Business, Diponegoro University, Semarang, Indonesia. \\ 2,3 Faculty of Economics and Business, Jenderal Sudirman University, Purwokerto, Indonesia \\ *e-mail corresponding author: riodhani@unsoed.ac.id
}

\begin{abstract}
Coal and oil are the two most important sources of primary energy in the world today. Since the historic collapse of Lehman Brothers helped precipitate the global economic crisis in the spring of 2008, a strong positive correlation between the price of crude oil continues to appear and the global stock markets, including the stock exchanges in Indonesia. This happens due to capital market investors assume that rising energy prices are a sign of the increasing global demand objective of this study was to determine the effect of crude oil prices and the price of coal on JCI in the Indonesia Stock Exchange in the period 2012 -2017. This study uses a timeseries data analysis tool Vector Autoregression approach. VAR model approach is considered more suitable for detecting a mutual relationship or a dynamic two-way causality between variables in world crude oil prices, the price of gold and the price of coal on the stock price index of the mining sector in the system of equations. The empirical results suggest that coal prices are affected by the supply and demand shocks of the oil market, while oil supply shocks have no effect on oil prices. This shows a high level of interaction between the crude oil market and the coal market, arising mainly due to the role of substitution.
\end{abstract}

Keywords: crude oil, coal, VAR model JEL Classifications: Q41, Q43

\begin{abstract}
Abstrak
Batubara dan minyak adalah dua sumber energi utama terpenting di dunia saat ini. Sejak runtuhnya historis Lehman Brothers membantu mempercepat krisis ekonomi global pada musim semi 2008, korelasi positif yang kuat antara harga minyak mentah terus muncul dan pasar saham global, termasuk bursa saham di Indonesia. Hal ini terjadi karena investor pasar modal beranggapan bahwa kenaikan harga energi merupakan pertanda meningkatnya permintaan global dari penelitian ini adalah untuk mengetahui pengaruh harga minyak mentah dan harga batubara terhadap IHSG di Bursa Efek Indonesia pada periode 2012 - 2017. Penelitian ini menggunakan alat analisis data deret waktu dengan pendekatan Autoregresi Vector. Pendekatan model VAR dianggap lebih cocok untuk mendeteksi hubungan timbal balik atau hubungan dua arah yang dinamis antara variabel dalam harga minyak mentah dunia, harga emas dan harga batubara pada indeks harga saham sektor pertambangan dalam sistem persamaan. Hasil empiris menunjukkan bahwa harga batubara dipengaruhi oleh guncangan penawaran dan permintaan pasar minyak, sementara guncangan pasokan minyak tidak berpengaruh pada harga minyak. Ini menunjukkan tingkat interaksi yang tinggi antara pasar minyak mentah dan pasar batubara, yang timbul terutama karena peran substitusinya.
\end{abstract}

Keywords: crude oil, coal, VAR model, JEL Classifications: Q41, Q43

\section{INTRODUCTION}

In the globalization era, many investors prefer investing in various sectors such as property and manufacturing sectors. In addition to these two sectors to invest in the mining sector also attracted many investors because they think the sector can provide a sizeable return on the long term. Mining is an integral economic driver for Indonesia. The mining sector has become an increasingly strategic sector for Indonesia it can be seen from the mining resources owned by 
Indonesia. Many theories and previous research revealed that the composite stock price index is influenced by several factors.

Three factors including the price of gold, crude oil prices and the exchange rate of the global financial crisis. It greatly affects the economic condition in the country (Zamani, 2016). One of the effects of the global financial crisis is slowing economic growth in Indonesia in 2008. Conditions in the balance of payments current account deficit continuously, and realized crude oil prices increasingly erratic, efforts to increase the acceptance of non-crude oil exports are absolutely necessary. These direct effects also affect the stock index in the capital market.

Based on information and JCI which fluctuates with the push factor, the authors are interested in creating research entitled "Analysis of Effect of Crude oil Price and Coal Against JCI. Based on the background of the above problems, it can be given the problem in this research is how to influence the price of crude oil and the price of coal on the JCI in 2012 -2017. The purpose of this research are as follows: To determine the effect of crude oil prices and the price of coal on JCI in the Stock Exchange in the period $2012-2017$

\section{LITERATURE REVIEW AND HYPOTHESIS DEVELOPMENT}

Crude oil, also known as Crude Crude oil is a commodity and major world needs today. Even Indonesia also experienced the crude oil crisis at the moment. The output of crude oil used daily is diesel, gasoline, Betamax, etc. Amounting to $84 \%$ of the crude oil will be processed into vehicle fuel (gasoline), aircraft fuel and jet (diesel), heating the material earth (heating), other fuels and liquid gas (liquefied petroleum gas). Barel is the unit of currency of crude oil to the dollar exchange rate. The selection of the dollar as a medium of exchange for crude oil and gold is denominated in USD is known almost all over the world.

\section{Composite Stock Price Index (CSPI)}

Composite Stock Price Index (CSPI abbreviated, in English called the Jakarta Composite Index, JCI, or JSX Composite) is a stock market index used by the Indonesian Stock Exchange (BEI; formerly Jakarta Stock Exchange (JSX)). First introduced in April 1, 1983, as an indicator of stock price movements on the JSE, this index covers price movements throughout the common stock and preferred stock are listed on the Stock Exchange.

The basis for the calculation of JCI Day is August 10, 1982. On that date, the index is set at 100 and the Core Value shares are listed at that time amounted to 13 stocks. The formula for calculating the composite stock price index (CSPI) is as follows.

COMPOSITE STOCK PRICE INDEX INDONESIA $(\mathrm{CSPI})=\left(\sum \mathrm{Ht} / \sum \mathrm{Ho}\right) \times 100 \%$ 


$$
\begin{aligned}
& \Sigma \mathrm{Ht}=\text { Total price of all shares at the applicable time } \\
& \Sigma \mathrm{Ho}=\text { Total price of all the shares on a timely basis }
\end{aligned}
$$

From the index price that we can find out if the market is crowded, lethargic, or in a stable condition. JCI Figures show above 100 means the market is crowded, while at JCI showed below 100 means the market is sluggish, JCI shows the value of 100 means the market is in a stable condition.

\section{Effect of Crude Oil Prices Against JCI}

Crude oil, also known as Crude Crude oil is a commodity and major world needs today. Since the historic collapse of Lehman Brothers helped precipitate the global economic crisis in the spring of 2008, a strong positive correlation between the price of crude oil continues to appear and the global stock markets, including the stock exchanges in Indonesia. This happens due to capital market investors assume that rising energy prices are a sign of growing global demand, which means the improvement in the global economic recovery after the crisis. By contrast, energy prices fell reflecting a weakening of global economic recovery (Laksana, et.al, 2017). Thus, if the price of crude oil increased, expectations for the improved performance of these companies will also increase and

The movement of crude oil prices is also an indication that affects the stock market of a country. Indirectly rise in world crude oil prices will impact the export and import sector of a country (Laksana et.al, 2016). For crude oil-exporting countries, the increase in world crude oil prices is a distinct advantage for the company (Zellou,2012). Because the prices are high making investors tend to invest their funds into various sectors of the crude oil and mining commodities. However, if crude oil prices were declining, investors tend to take profit (profit taking) by selling shares (Maulino, 2009).

The increase in world crude oil prices more negatively affect the stock price index (CSPI), because the government was not able to continue - constantly maintaining subsidized fuel crude oil (BBM), then the government raised fuel prices. The increase in fuel will cause a negative climate on the domestic economy, due to rising inflation and reduce the amount of demand for goods. This makes the company's share price (issuers) decreased so that the Price Index (JCI) also decreased. So the relationship between world crude oil prices with JSX Composite was negative.

\section{Effect of Coal Prices Against JCI}

Coal is a natural resource belonging to the state government to ensure the availability of coal for domestic needs. For the national interest, the government is able to control the production and 
export, transfer of ownership of coal between the government and mining companies is through royalties. (Www.esdm.go.id, 2017)

Royalties are set based on the tonnage and price: PKP2B: 13.5\% x tonnage x price IUP: 3\% $\mathrm{x}$ tonnage $\mathrm{x}$ price. For the optimization of state, revenue comes from coal and avoid transfer pricing practices, required coal benchmark price (ESDM No. 17/2010 on procedures for determining the benchmark price sale of mineral and coal). Coal from different mines are also different in terms; calorific value, ash content, moisture content, sulfur content, hardness, size, and others. Purchases of coal have specific needs depending on the specifications of combustion facilities, government regulations, availability of storage (Lie, et al. 2010). Uncertainties faced by coal producers are price and profit margin rivals. While the uncertainty faced by users of coal is the continuity of supply in accordance with the expected quality and quantity, the sustainability of the production process.

Li et al. (2010) investigated the long-run relationship between international steam coal prices According to their cointegration test results; they found some evidence that the international steam coal market is generally integrated. Some researchers found evidence that "the world oil market, like the ocean, is one great pool," (Adelman [1984]). Some studies investigated the short-run and long-run relationships between crude oil, coal, and natural gas. Based on the background and formulation of the problem, the hypothesis in this study is world crude oil prices and the price of coal had simultan effect on JCI on the Indonesia Stock Exchange.

\section{RESEARCH METHODOLOGY}

\section{Sources and Types of Data}

In this study, the source of the data used is secondary data obtained by means of documentation, where the data obtained is not obtained directly from the object under study. Secondary data used in this study is the daily data of the rupiah, the world gold price, crude oil price and the period of January to December 2012- 20013 listed on the Stock Exchange as well as other information. In this study, the data obtained through the website www.idx.co.id, www.finance.yahoo.com, www.useconomy.about.com, and literature- literature related to the problems examined. While the types of data used in this research are quantitative data including data that emphasize testing the theory by measuring the variables with numbers and perform statistical data analysis procedures.

The data in this study include Stock Price Index data obtained from www.idx.co.id. This data is in the form of daily closing share price for the period 2012-2017; World crude oil prices were 
obtained from www.eia.gov each month for the period 2012-2017 and the benchmark coal price obtained from www.apbi-icma.com each month for the period 2012-2017.

\section{Operational Definition of Variables}

This study uses time-series data (time series) with the observation period from 2012 - 2017. The following is an operational definition of variables: Stock Price Index which reflects the numbers represent/reflect the movement of the entire mining sector shares listed on the Stock Exchange. Stock Price Index Data used in this study is the value of the average daily closing price of the Index monthly. World Crude oil Prices; The data used is the spot price of crude oil is formed from the accumulation of demand and supply. In this study, the world crude oil price used is the standard West Texas Intermediate (WTI) and Coal Prices which reference to a formula indexed to the ICI-1, Platts1, NEX, and GC. HBA is applicable to spot price sales (under 12 months). Weighted average HBA last 3 months applies to the sale of coal for 12 months. Data were taken from the reference coal www.apbi-icma.com.

\section{Method of Data Analysis}

This study will use a time-series data analysis tool Vector Autoregression approach. VAR model approach is considered more suitable for detecting a mutual relationship or a dynamic two-way causality between variables in world crude oil prices, the price of gold and the price of coal on the stock price index of the mining sector in the system of equations. Then, if the data used stationary at first difference, then the VAR model will be combined with the error correction model (error correction model) be cointegrated VAR or commonly known as the Vector Error Correction Model (VECM). Methods This study will describe the impulse response function and variance decomposition that is the property of the VAR model to see the shock of variable innovations on other variables.

VAR methodology was first discovered by Sims (1980). In his study Macroeconomics and Reality, VAR as a reaction to the failure of major macro-economic models to estimate the economic conditions in the 1970s. If indeed simultaneously on a group of variables should all variables have the same position, so that among the variables it is difficult to distinguish between endogenous and exogenous variables? Therefore, Sims doubt the existence of exogenous variables. Further, Sims also stated that to understand an economy just enough only takes a few variables, all of which are endogenous variables (Dritsaki,2005). So that in the VAR number of variables is used relatively little that is not more than six (6) variables.

Gujarati (1995: 620) explains that the VAR is a continuation of the Keynesian monetarist criticism. Some characteristics VAR show partiality to the monetarists, the VAR method first developed on the basis of criticism of these great models. Second, the VAR model offers a simple and use the number 
of variables is minimalist, with the independent variable is the slowness (lag) all the endogenous variables. Third, the VAR is a continuation of the causality test. VAR characteristics can not be separated from Granger causality characteristics, such as focusing on the study of identity.

In development by Autoregression Vector (VAR) is the development of a model of Auto-Regressive Distributed Lag (ADL). Within the framework of VAR, it is possible to estimate the range of variables suspected to have endogeneity. VAR models are built to overcome this where the economic relationship between variables can still be estimated without the need to underline the problem eksogenitas. In this approach, all the variables are considered as endogenous and estimation can be performed simultaneously or sequential (Ariefianto, 2012).

\section{RESULT AND DISCUSSION}

\section{Stationer test}

Table 1:

Stasioneritas Dickey-Fuller Test

\begin{tabular}{ccc}
\hline Variable & Significant (Level) & Coefficient (1 ${ }^{\text {st }}$ Diff $)$ \\
\hline COMPOSITE & 0.7659 & 0.0000 \\
STOCK PRICE & & \\
INDEX & & \\
INDONESIA & & - \\
(CSPI) & 0.0003 & 0.0000 \\
Crude oil Price & 0.8839 & \\
Coal Price & & \\
\hline
\end{tabular}

Based on Table 1 it can be seen the significant value of the Dickey-Fuller test Test on the observed variables. The conclusion of the stationary Dickey-Fuller test Test test is a variable crude oil price at the current level stationary. While variable JCI and world crude oil prices, stationary at 1st level Difference.

\section{Cointegration test Crude oil dan Coal}

Tabel 2. Cointegration test Crude oil dan Coal

\begin{tabular}{ccc}
\hline Index & Trace statistic & Critical Value \\
\hline COMPOSITE STOCK & 78.70623 & 24.27596 \\
PRICE INDEX & & \\
INDONESIA (CSPI) & & \\
\hline
\end{tabular}

Thus the results of the cointegration test against residual reinforce that among the variables used because there is cointegration trace statistic value is greater than the critical value ya. Cointegration tests conducted to obtain the long-term stable relationship between the variables are integrated on 
the same degree. It shows also that there is a long-term balance between variables, world crude oil prices, the price of coal and JSX Composite (JCI). In each short term period, each of the variables tends to adjust to achieve a balance in the longterm.

\section{Evaluation of ARIMA Modelling}

Best Output Model:

$$
\begin{aligned}
& \mathrm{D}(\text { COMPOSITE STOCK PRICE INDEX INDONESIA (CSPI) })=\mathrm{C}(1)+ \\
& {[\mathrm{MA}(17)=\mathrm{C}(2), \mathrm{BACKCAST}=2, \mathrm{ESTSMPL}=" 284 "}
\end{aligned}
$$

\section{ARCH Test}

Crude Crude oil effect to COMPOSITE STOCK PRICE INDEX INDONESIA (CSPI)

Tabel 3. Heteroscedasticity Test ARCH

\begin{tabular}{ll}
\hline F statistic: 0.005516 & Prob. F: 0.940976 \\
\hline Obs* R Squared: 0.000068 & Prob.Chisquare (1): 0.9410 \\
\hline
\end{tabular}

Based on the calculated value of $\mathrm{R}$ squared observation: with Chi-square 0.000680 .9410 then indicate that there are effects on the ARCH model is estimated.

\section{Coal effect to COMPOSITE STOCK PRICE INDEX INDONESIA (CSPI)}

Tabel 4. Heteroscedasticity Test ARCH

\begin{tabular}{ll}
\hline F statistic: 2.290394 & Prob. F: 0.134069 \\
\hline Obs* R Squared: 0.027499 & Prob.Chisquare (1): 0.1341
\end{tabular}

Based on the calculated value of R squared observation: 0.027499 with Chi-square: 0.1341 then it indicates that there are effects on the ARCH model is estimated.

\section{Model Estimation Error Correction Model (ECM)}

After testing the stationarity and cointegration test is then performed prediction equation coefficients on the Error Correction Model (ECM). Model Error Correction Model (ECM) characteristic possessed by the inclusion of elements of Error Correction Term (ECT) in the model. If the ECT coefficient is statistically significant, the specifications of the model used in the study were valid. Model specification, dilajutkan hypothesis testing either simultaneously or partially.

Table 5

\section{Error Correction Model (ECM)}

Variable Coefficient t-statistik Probability




\begin{tabular}{llll}
\hline Crude oil & -4.561442 & -1.509475 & 0.1351 \\
Coal & -0.761636 & -0.398442 & 0.6914 \\
Constanta & 476.4584 & 1.610172 & 0.1113 \\
\hline
\end{tabular}

Regression equation:

D(COMPOSITE STOCK PRICE INDEX INDONESIA (CSPI)) $=476.458378397$ -

4.56144248499*CRUDE OIL - 0.76163585195*D(COAL)

In Table 5 regression estimation ECM short term, the F test, the F-statistic of 1.162 with a probability of 0318 while the value of the F-table at 3.11 on a critical value $\alpha=5 \%$, so the F-count is greater than F-table or $1.16<3.11$. It can be concluded free variables (the price of crude oil and coal) simultaneously does not affect the dependent variable (JSX Composite). R-squared value in the estimation model ECM is 0,028 , this means that $2 \%$ of JCI variation can be explained by variations in the variable world crude oil prices and coal in the short term, while the remaining 98\% is explained by variables - other variables outside the model.

\section{CONCLUSION}

In this research allegedly World Crude oil Prices and the World Coal Prices negative impact on JCI ". Based on calculations, the hypothesis is proven This is because the world price of crude oil and coal has a negative impact on JCI though not significantly. For the movement of world crude oil prices, it will be followed by the movement of the price of fuel crude oil (BBM) in Indonesia. The fuel price hike will give the effect of an increase in prices of goods and services so that the demand for goods will be dropped. The decline in demand for these goods and services will lead to a decline in income investors. The result explained against JCI world crude oil prices due to significant negative in the short term, crude oil price movements underestimated by investors in making an investment.

That during the study period, the regression models increase in crude oil prices will have an impact decline in JCI, this is due to the rise in crude oil prices in the short term will be a direct response by the government to raise the price of fuel crude oil (BBM) in Indonesia to raise fuel prices, demand for goods or services with best will reduce the income investor. As for the long-term increase in the world, crude oil prices will impact the increase in JCI, because, in the long run, the old society's time we're familiar with rising crude oil prices so that demand for goods or services will return to normal, and JCI will increase.

With the number of issuers in the stock price index in Indonesia is largely not a company directly related to crude oil commodities. The amount of coal production produced in Indonesia has 
increased from year to year. However, consumption or demand for coal in Indonesia has decreased from 2016 to 2017. This study only focuses on examining aspects of coal and oil commodities without other commodities such as tin, copper, etc.

In addition to the amount of production and consumption, there are other factors that are the cause of the effect of coal prices on the mining sector stock price index. Another factor is the absence of a holding company in the coal sub-sector. Even though the holding company can manage, build and control performance between companies. When the company's performance is good, it will invite positive reactions from investors. Whereas in the coal sub-sector there is no holding company that has made investors not yet invited positive reactions from investors and coal companies which are still underperforming compared to other sectors such as the consumption sector, banking, and others. The increase and decrease in world coal prices did not affect the composite share price index and the stock price index of the mining sector in Indonesia.

\section{BIBLIOGRAPHY}

Hayo, Bernd dan Ali M. Kutan. 2004. The Impact of News, Crude oil Prices, and Global Market Developments on Russian Financial Markets, William Davidson Institute Working Paper Number 656. Michigan University.

Boonyanam, N. (2014), Relationship of stock price and monetary variables of Asian small open emerging economy: Evidence from Thailand. International Journal of Financial Research, 5(1), 52-63.

Brigham, E.F., Houston, J.F. (2007), Essentials of Financial Management. Singapore: Cengage Learning.

Chen, N., Roll, R., Ross, S.A. (1986), Economic forces and the stock market. Journal of Business, 5(9), 383-403.

Dritsaki, M. (2005), Linkage between the stock market and macroeconomic fundamentals: a Case study of Athens stock exchange. Journal of Financial Management and Analysis, 18(1), 38.

Hsing, Y. (2013), Impact of macroeconomic variables on the stock market in Slovakia and policy implication. Economics and Economy, 1(1), 7-16.

Issahaku, H., Uztarz, Y., Domanban, P.B. (2013), Macroeconomic variables and stock market returns in Ghana: Any causal link? Asian Economica and Financial Review, 3(8), 1044-1062. 
Izedonmi, P.F., Abdullahi, I.B. (2011), The effects of macroeconomic factors on the Nigerian stock returns: A sectoral approach. Global Journal of Management and Business Research, 11(7), 25-29.

Khan, F., Ahmad, A.M., Choo, L.G., Bokhari, M. (2014), Economic exposure of stock returns on Karachi stock exchange: Substantiation from both aggregate and disaggregate data. International Journal of Information Processing and Management, 5(2), 10 22.

Laksana, R.D., Hersugondo, H. (2016): Does economic value-added influence the shareholder value in Indonesia?, International Journal of Applied Business and Economic Research. Vol. 14, No. 3, (2016): 1547-1560

Laksana, R.D, H. Hersugondo, S. Wahyudi, H. Muharam (2017), The New Decomposition Asset Growth Effect. An Empirical Evidence of Indonesia, Journal of Applied Economic Sciences, 12(4), 977-984

Li, R., Joyeux, R., Ripple, R.D. (2010), International steam coal market integration. The Energy Journal, 31(3), 181-202. [íc]

Zamani, N. (2016), How the crude oil market affects the natural gas market? Demand and supply shocks. International Journal of Energy Economics and Policy, 6(2), 217221.

Zellou, A.M., Cuddington, J.T. (2012), Trends and Super Cycles in Crude Oil and Coal Prices. Colorado School of Mines, Division of Economics and Business, Working Paper No. 2012-10. 